\title{
6
}

\section{Youth Leadership in Fiji and Solomon Islands: Creating Opportunities for Civic Engagement}

\author{
Aidan Craney
}

\section{Introduction}

The strength of civil society across communities in Oceania varies. The hierarchical nature of 'traditional' communities can act as a limiting factor in citizens' active participation in civil society, with Oceanic societies generally prescribing the roles that each member of the community is allowed and entitled to perform. Thus, despite the long histories of group decision-making processes for most Pacific societies, it remains that power is primarily wielded by adult men (McLeod 2015; Prasad 2017, p. 331; Sahlins 1963), though senior women have greater influence in some matrilineal societies, particularly outside Melanesia (McLeod 2007, pp. 10-12, 2015).

Despite this, change has been present in recent years, resulting in an expanded and emboldened civil society sector in certain spaces. The combination of enhanced information flow through telecommunications technologies, the growing levels of educated citizens and the influences of globalisation such as through the expansion of the international development industry-including through regional multilateral bodies - has resulted in civil society groups and development 
organisations critically engaging with and, at times, challenging authority in the region (Brimacombe 2017; Brimacombe et al. 2018; Titifanue et al. 2017). Moving from 'sporadic' responses to immediate issues of concern, such as Fiji's 1987 military coups (Slatter 2006, p. 29), these groups, both formal and informal, are now engaging in sustained campaigns that are both sociocentric and issues based.

Notably, the increasingly politicised civil society activities of the recent past have largely been driven by, or made inclusive of, youth. This is despite the continued minimisation of the roles that they play and have the potential to play in their communities. Particularly in fields related to social justice, such as gender rights, sexuality rights and climate change, young people are at the vanguard of change and are forcing their way into the public consciousness and conversation.

This chapter discusses how a growing cohort of young people in Fiji and Solomon Islands are creating spaces for themselves to act as social justice activists and advocates for advancing youth opportunities. Through three case studies, I present examples of how these young people are resisting the structural minimisation of youth in Pacific societies to assert their rights to be full and active citizens. The chapter draws on data that were collected during fieldwork conducted in Fiji and Solomon Islands in 2015 for my doctoral thesis, in which I examined the social roles and livelihood opportunities of youth in these countries. I show how some young people in the Pacific are finding ways to proactively and pro-socially engage in critical civil society, despite the cultural expectations of their subservience.

\section{The Structural Minimisation of Pacific Youth}

The influence of hierarchy in Oceanic societies can scarcely be overstated. Social roles are generally well established and align with an individual's lineage, gender and age (Brimacombe 2017, p. 144; Cox 2017, p. 77; Jolly 1994; Morton 1996, pp. 22-24). Other factors with greater variability such as ability, sexuality, education, occupation and marital status also play a part. For youth, such hierarchy underscores the roles and influence that they can have in their communities. ${ }^{1}$ This is commonly marked by

1 Definitions of 'youth' in the Pacific vary. The term is usually applied to people aged 15-35 who have not married, are not parents and/or have not achieved other milestones that are socially associated with adulthood, such as being employed. 
an expectation of deference and a lack of deliberative participation. In the words of Tura Lewai, a civil society and gender rights activist from Fiji: 'Young people are taught to be seen but not heard'.

This marginalisation of youth voices extends to youth representatives often not being young themselves. Kaajal Kumar, a youth and civil society activist from Fiji, spoke to me of the propensity of such representatives to be disconnected from current trends and issues affecting youth, but to be holding on to the position of influence that they have obtained. She told me:

What you see in the Pacific-you come across young people who are 30 or 40 , who are in the youth movement. If you look at [name of organisation], the person holding the youth desk, how old is that person? Because it took them time to get there, they have an ideology. And the youth movement, the way it functions, is that our ideas keep changing.

Discouraging youth participation enculturates young people to occupy a subordinated position in society. In a report on increasing youth participation in the Pacific, commissioned by the World Bank, youth development advocates Shasheen Jayaweera and Kate Morioka (2008, p. 11) explain that in a Pacific context, 'Young people are expected to accept authority without question, to the extent that they are discouraged from sharing their ideas and suggestions with elders'. Despite this, examples exist of young Pacific people expressing a desire to be more actively involved in the planning and decision-making processes of their communities, countries and cultures. At the 2nd Pacific Youth Festival in 2009, over 300 young people from across the region declared: 'As young people, we are important human resources to development, and have an important role to play in building families, communities, institutions and nations; and in all sectors, both formal and informal' (SPC 2009, p. 2). ${ }^{2}$ This sentiment is mirrored in the responses that Jayaweera and Morioka were exposed to from young Pacific people discussing their wishes to be engaged citizens. They point out that: 'Whilst some cultures actually discourage young people from expressing their views, it was the heartfelt desire of youth to become active citizens who could make a worthwhile

2 A further example of youth minimisation: though two Pacific youth festivals were organised in 2006 and 2009 to provide youth from across the region to engage in visioning and decision-making processes, a third such festival is yet to occur. 
contribution to their nation' (2008, p. 10). Moreover, it is evident in the growing examples of young people inserting themselves into spaces of active civic participation, as highlighted in the case studies in this chapter.

The minimisation of youth engagement in home and village settings is replicated in the formal policies and processes of decision-making. Such minimisation even flows through to academia, with Fijian youth researcher Patrick Vakaoti writing in relation to youth civic participation in Fiji that 'literature on Fiji's political history has failed to offer any detailed analysis about young people's involvement in politics' (Vakaoti 2012 , p. 8). Regionally, this minimisation is most notable in the repeated lack of mention of youth in the progress reports of the Pacific Plan (Noble et al. 2011, p. 16) and similar documents outlining the foci and ambitions of the 18 member states of the Pacific Islands Forum. It was further reinforced in April or May of 2018, when the youth-focused page on the Pacific Islands Forum Secretariat, which had remained 'under construction' (PIFS n.d.) for many years, was removed entirely from the website. Such examples act as evidence not only of the assumed lack of influence of youth within Pacific societies, but of the recurrent failures to acknowledge, understand and address their realities.

Whether by design or simply reflecting notions of tradition, the result of the youth voice being ignored amounts to a structural minimisation of the worth and potentiality of youth. To borrow a term from citizenship scholar David Owen (1996), youth are not considered to be active citizens, but instead 'apprentice-citizens' who need to be managed, rather than consulted, and taught, rather than learned from (see Bessant 2004; Harris 2006). As Jayaweera and Morioka (2008, p. 11) noted, 'Even if adults understand youth concerns, they are perceived as unlikely to prioritize them or take action to address them'.

\section{Rationalising Power Imbalances}

Several youth activists and advocates spoke to me of the frustration that they felt within Pacific youth communities regarding the lack of opportunities present for their active engagement in civil society. Primarily, their participation is considered by youth and youth advocates to be overlooked by decision-makers rather than explicitly opposed. As Patrick Mesia, a youth-focused development worker from Solomon Islands, said to me: 
Because of some of the cultural context here in Solomons, like the big man system, the elders in some places dictate what should happen sometimes for a young age group like that. They don't give them space and when they hear them raising issues, they ignore it as being from a pikinini [child] point of view.

This ignorance of youth engagement was discussed as being reflective of cultural practices that do not place importance on the role of youth as potential decision-makers and active citizens. In these scenarios, youth and adults alike are unlikely to consider active youth involvement in decision-making processes. Some informants, however, shared their experiences of youth populations who were resisting their minimisation rather than passively accepting it. These communities were marked by young people, who were forthright in their intention to be engaged members of their societies, meeting opposition from adult communities who were unaccustomed to assertive youth populations. Not content to be considered citizens in waiting, these young people were agitating to be viewed and included by their societies as active citizens.

Salote Kaimacuata, a child protection specialist at UNICEF Pacific and former magistrate in the Fijian judiciary who oversaw juvenile hearings, informed me that this is a problem throughout Oceania. She reflected on her experiences of working with young i-Kiribati women for UNICEF Pacific:

I-Kiribati youth have been asking for a long time: 'Can we sit there?'; 'Can we participate?'; 'Can we input? Because our time will come sooner than we want, and we need to learn now from you and be mentored by you'.

Mamta Chand, a women's human rights activist from Fiji, described her dismay at the women's movement's rigid leadership structures and lack of acknowledgement of successes, saying:

When we are in the intergenerational spaces, young women are told, 'You're not leaders. You're the leaders of tomorrow.' It was really frustrating. We would say, 'We are leaders of today. We are doing things. We are mobilising young women. We've mobilised young women to go and vote. We did that ourselves.' They refused to see us as leaders of now, of today. They say, 'No, when we die you become leaders.' We are leaders. We are leading. They refuse to accept that. 
Usaia Moli, a youth advocate and former chair of the National Youth Council in Fiji, conveyed the same experience of engaging with the resistance of adult leaders to active youth citizenship. He said:

No longer they can point to us and say, 'You'll be the leaders of tomorrow', because we are making changes right now. We look at every issue that comes up around the country and we have become champions on these issues in our own way. We represent the country in international meetings and presentations and everywhere we go, but yet they keep telling us, 'You are the leaders of tomorrow. Your time will come.' Our time is now. I don't have to wait a few more years.

Across the Pacific, opportunities for invited, engaged participation of youth in civil society are few. This is evident in formal spaces, such as the limited representation of youth interests in formal governance systems, including parliaments (Noble et al. 2011, p. 19). Less obvious are how social expectations are placed on youth, which limits their ability to be decisive about choices that will affect their long-term livelihoods, such as the pressures placed on children and youth to pursue education and the employment pathways that are associated with status rather than matched to their individual attributes or likely future livelihood opportunities (Nilan et al. 2006). Further, Fijian youth researcher Mereia Carling and Solomon Islands youth group leader John Firibo shared with me that when youth attempt to create space for themselves to represent their views, they are derided for disrespecting how their cultures operate and for disrespecting the wisdom of vesting authority in their elders.

Even with all these constraints to their active citizenship, growing numbers of young Pacific peoples are forging their own pathways to being active and engaged members of their societies, prosecuting the case that young people can and should be involved in decision-making processes. The following three case studies provide evidence of this. The first documents the influence that a small group of young people in Fiji were able to have on shaping public discourse ahead of the 2014 general election. The second discusses how a regional climate change-focused advocacy group is refusing to remain silent in the face of catastrophic environmental destruction. The last assembles examples of how young people in Fiji and Solomon Islands are creating spaces for the development of youth skills and voice in various contexts. 


\section{Case Study I: Be the Change}

Before the Fijian general election of 2014-the country's first election since the 2006 coup d'état-Roshika Deo decided to run for parliament. With a professional background in law and international development, as well as a long history of social justice activism, Deo sought to use the campaign process to highlight the inequities that she noted in her home country, providing a voice for youth and women.

Deo built a small support team and consulted with established parties about standing for them, before choosing to run as an independent. As she explained:

In the beginning we went to two political parties. We sat in meetings, spoke to people and we realised that they were very much conformist and there were rigid hierarchies. I realised that if I went in that party, I would only be perpetuating the same systems that are there by being part of it. I wouldn't be doing anything new. Nothing would change.

When determining to run as an independent, however, Deo decided to acknowledge the significant support network that she was building and labelled her campaign as 'Be the Change'.

Running on a social activist platform, Deo and Be the Change challenged social and political orthodoxy by not only openly discussing issues such as abortion, domestic violence and same-sex marriage, but by taking progressive positions on each of these issues, which contrasted with the conservative stances of the major parties. Her campaign shaped much of the public narrative of the election by pushing these boundaries. She told me:

Fiji Sun [newspaper] was running an opinion article, so the candidates could write opinions and submit. Parties could write so I said, 'Be the Change is like a party. It's functioning like a party, so let's write.' Then I started getting other young people to write together with me. When we wrote about mental health issues, the next two or three days after we noticed that the media had started asking all the candidates about mental health. Once, when we wrote about LGBTIQ rights, on [television station] Fiji One, they asked all the candidates about same-sex marriage. 
Of the campaign's influence, Deo said:

We raised a lot of issues that no one else was talking about: things around LGBTIQ rights-no one used to talk about it, so as soon as we started talking about, the media started talking about it; violence against women - no one talked about violence against women as comprehensively as we did; also demilitarisationpeople did talk about militarisation but we talked about it in terms of the impact on young people and women, moving away from generic discussions on militarisation. It was a bit more abstract, so we started contextualising it.

The campaign not only influenced media reporting and forced other candidates to discuss uncomfortable positions, it also opened Deo up to significant criticism from across the community, which regularly went beyond analysis of her political positions. She was criticised for her stance on gender, religion and culture, among other subjects (Chattier 2016; Palet 2014). She even told me:

They had a [picture of a] full-born dead baby that they circulated all over Facebook, saying 'Roshika Deo supports abortion'. Very aggressively and loudly, I got attacked in that space.

The effect of such criticism did not silence Deo, however. She continued her campaign, narrowly falling short of being elected. ${ }^{3}$ Her influence can be seen in her ability to attract over 1,000 votes in the general election, over 14,000 likes on the Be the Change Facebook page (Chattier 2016) and by the ability of her campaign to dictate much of the election's narrative. Demonstrating the capacity for organised youth to influence civic discourse, Roshika highlighted to me the motivation that she took from some of the more distasteful forms of criticism that she received when she realised why it was occurring, stating that 'we're challenging the status quo'.

\section{Case Study II: 350 Pacific}

350.org is a global grassroots social movement focused on combating human-induced climate change (350.org n.d.). The organisation has a diversified structure, with the main office based in New York and other

3 Due to eligibility legislation, Deo was not able to contest the 2018 election as a result of spending too great a period of time outside of the country undertaking study following the 2014 election. 
satellite bodies throughout the globe, representing cities, countries and regions. Most of its members are volunteers who engage in advocacy campaigns that can be locally led or coordinated through a regional office.

350 Pacific is the arm of the organisation representing the region that incorporates Australia, Aotearoa/New Zealand and the Pacific Islands, ${ }^{4}$ with a permanent staff member based in each of Australia, Aotearoa/New Zealand and Fiji. ${ }^{5}$ There are active 350 Pacific groups across 15 Pacific states. Though membership across the 350 global network is not restricted by age limits, the Pacific groups almost exclusively consist of persons aged under 35. Their membership reflects their belief that, as it is young people who will mostly feel the effects of human-induced climate change, they should lead the efforts to combat it.

The Pacific-based group, who identify as the 'Pacific Climate Warriors', have not let their age negatively affect their engagement in advocacy and reform programs across the region, as well as beyond. Rather than relying on recognised government, private sector or civil society leaders to guide climate change advocacy and reform efforts, the members of 350 Pacific have insisted on having their voices be heard by domestic, regional and international leaders and change makers.

Traditional methods of advocacy that they have engaged in include direct lobbying to decision-makers and facilitating demonstrations (350 Pacific n.d.). Overcoming some of the barriers that are related to geography and timeliness, 350 Pacific has engaged in electronic campaigns to contact local representatives, as well as share images and videos of their daily climate-affected realities with the global community (Carter 2015, p. 26).

To register an effect that is both current and sustainable, 350 Pacific members have recognised that ideas of leadership that their communities held are vital to influencing change, but rather than ceding authority to those seen as leaders purely because of their age, they should instead question what leadership looks like. Fenton Lutunatabua, 350 Pacific's Fiji-based Communications Coordinator, explained to me that the organisation seeks to embed a sense of ownership and leadership in

4350 Pacific was created by a group of volunteers whose values aligned with the global 350.org movement, which developed into a formal partnership. Its volunteers are recruited through member networks.

$5 \quad$ As at the time of fieldwork in 2015. 
the communities that it works with, by responding 'to the needs of the community ... in ways that make sense to them so they can take full ownership of and encourage leadership from the ground up'.

Beyond this, 350 Pacific actively targets young Pacific people that it considers agents of change to become members and to lead their home country initiatives. Regional representatives include members of the Pacific Youth Council, Commonwealth Youth Council and senior staff from Pacific-based development organisation offices. In regard to their worth to the movement, Lutunatabua claimed:

These people are well connected. They're leaders in their own right. Really, they're doing the climate movement favours. Do we take claim to developing them? No. They have built their own reputations, they have networked so well, they have empowered so many people. It is us just connecting with them and trying to look at ways in which we can take their experience with the justice movements that they're in and apply that to the climate justice movement.

These youth leaders have been influential in securing positions in regional decision-making processes, such as the drafting of the current Pacific Youth Development Framework (SPC 2015).

The most disruptive 350 Pacific campaign to date occurred outside the Pacific Islands and focused on the damage being done to the planet by the region's neighbour, Australia. In 2014, 30 young Pacific people blockaded the largest coal port in the world in Newcastle on traditional canoes, with scores of non-Pacific people joining in support, stopping all 10 scheduled ships passing through (Packard 2014). The success of this action led to a 350.org repeat blockade in 2016 (Connell et al. 2016). Explaining the action, Lutunatabua stated that the purpose was:

To send a very clear message to the fossil fuel industry saying that, as Pacific Islanders, we will do what it takes to stand up for our Pacific and show the world that, if they continue to expand the fossil fuel industry, that's literally exporting destruction to the Pacific.

The campaigns and influence of 350 Pacific illustrate how some Pacific youth are identifying gaps in how issues of social justice are being addressed by their leaders. Where such deficits exist, young people are acting decisively to fill these gaps as advocates and activists. 


\section{Case Study III: Emerging Youth Activists}

Throughout Fiji and Solomon Islands-and particularly in the capitals of Suva and Honiara - a growing cohort of youth activists is creating spaces for other young people to develop personal and professional skills, as well as acting to influence policy agendas. The most obvious space in which this is occurring is the various youth councils at regional, national and subnational levels.

It is in the youth councils that young people like the Honiara Youth Council president, Harry Olikwailafa, have been able to develop their leadership skills and their exposure to decision-making processes and professional networks, to reach positions in which they can advocate for positive outcomes in youth policy planning. Harry has worked with youth councils and non-government organisations at local and regional levels to create and provide feedback on programs and policies. It was this experience that provided him skills and confidence, and that prompted him to pre-emptively create a youth policy paper to present to elected representatives following the 2014 general election during the period of government consolidation. ${ }^{6}$ As Harry told me:

I went to the camps at the different hotels and I sat with the elected members of parliament and presented the policy paper. I said, 'When you rub shoulders to form a government, remember young people'.

Beyond formal youth councils, young people have in recent years also begun to create their own organisations to develop youth capacity and participation. Kaajal Kumar, from Fiji, created the Aspire Network in 2012, with the mission of 'Developing Young People to Develop the Future Generation through Democratic Innovations' (Aspire Network 2012). Kaajal informed me that she wanted to create opportunities beyond youth councils, as their representative structure limits the amount of young people that they can upskill and expose to active civic engagement. To achieve such ends, the Network has engaged in activities such as hosting 50 Fijian youth at the Young Fijian Leaders Parliament Forum and Youth Parliament, which was established by the network in 2014.

6 Solomon Islands politics follows an ad hoc tradition whereby elected independent representatives are courted to create coalition governments. To try to secure numbers, aligned representatives are segregated into 'camps' at different locations to try to prevent them from being courted by opposing groups (Fraenkel 2008; Wood 2015). 
A former member of the Fijian National Youth Council, Elisha Bano, takes a different approach to developing youth skills in active civic engagement. In 2014, she established ACT Fiji, standing for Advocacy through Creative Techniques. As Elisha explained to me:

It's a youth advocacy group where we are trying to use creative mediums to advocate on social issues. There are three mediums that we are targeting: social media ... theatre, and ... graphic arts.

Elisha is one of a growing number of Fijians using artistic endeavours to influence civic discourse through what is referred to in Fijian critical civil society as 'artivism'.

Finally, from a more formal development perspective is the example of Sandra Bartlett. At the age of 27, Sandra was hired to manage the employment training program in Solomon Islands, Youth@Work. Unlike the examples of Harry, Kaajal and Elisha, Sandra's history as a youth advocate is purely professional. Hired based on her education and business background, Sandra utilised her age to be a mentor to the youth participants of the program, while also using her professional skills to create a positive image of youth to businesses, communities and media in Honiara. With more than 500 young people completing the training and internship program between 2009 and 2015, Sandra noted that:

The big success, the social change success, is that we've put youth development on people's minds. In Solomons, it was always, 'youth are a problem; youth are a time bomb; it's an issue, it's an issue ...', but now they see that youth are doing things.

\section{Unlocking the Potential of Pacific Youth}

Despite conceptions of 'tradition' that normalise youth minimisation, there is a small but growing recognition that providing opportunities for young people to develop their skills is required not only as a safeguard against antisocial behaviours and civil unrest, as per conventional readings of youth bulge theories (Sukarieh \& Tannock 2017; Urdal 2006), but it is also required to create and sustain positive developmental futures for the great ocean states of the Pacific. This is particularly true in institutional settings that address youth development issues directly or indirectly. Many of my informants discussed this with me. Luisa Senibulu, who has run anti-corruption workshops with young people from across the region, said: 
Youth have a lot to contribute. It is often said that they are the leaders of tomorrow. They have a lot of capacity. They have a lot of knowledge that we don't really utilise.

Former chair of Fiji's National Youth Council, Usaia Moli, stated:

If you're going to plan for the future, then it is only right that you include those that are going to be there, and that is the young people.

These sentiments were shared by Mereia Carling, who has researched youth citizenship in Fiji and who is the primary author of the current Pacific Youth Development Framework. She said:

We are never going to solve the problems that we want to solve by ignoring what young people think and not involving them. We are creating problems when we don't involve young people.

Beyond this, some young people continue to demonstrate their willingness to be leaders of their communities. This is particularly evident in responses to issues that are observed as having social and economic consequences. On issues of climate change and civil rights, it is youth who are making themselves experts and demanding that their voices be heard. No two examples better display this than the work of 350 Pacific in relation to climate change and Roshika Deo's 'Be the Change' political campaign of 2014. These examples support political scientist Patrick Kaiku's $(2017$, p. 7) criticism of the application of youth bulge theories in Melanesian societies: 'Where the youth bulge discourse generally depicts young people as impulsively violent and conflict-prone, it disregards youth-led initiatives that are worth knowing and supporting'. Notably, in each of these cases, the youth that were involved created the space for their engagement in areas in which deficits existed that the traditional ideas of leadership had not filled and reinforced-social justice-led politics, climate change and youth civic engagement.

The active and open participation of a growing number of Pacific youths in civil society reflects a growing sense of both optimism for change and despair at the status quo. Though the numbers of actively and civically engaged youth remain small, their influence is growing. This shift cannot be attributed to one singular cause. Fijian academic and social commentator Jope Tarai reflects that one reason may be an increased 
awareness for the youth's potential to drive change, saying: 'The projected youth population in the elections is 47 per cent, so we hold the highest majority of the mandate, so to speak'.

A combination of access to information, a growing network of youth who are engaged in critical civil society, disenfranchisement at the state of politics and a renewed focus on democracy throughout the region also appear to be playing a part.

Access to information has long been recognised as important for shaping individual and collective thought patterns. From Alexis de Tocqueville's (1947) assertion in 1835 that the strength of democracy in the US was largely due to a free and informative media, through to the influence of television on the civil rights movements globally in the mid-twentieth century (Klarman 1994, p. 11; Winter \& Eyal 1981), the flow of information has shaped politics and political engagement. As critical race and gender activist and author bell hooks (1990, p. 3) wrote, 'Watching television in the fifties and sixties, and listening to adult conversation, was one of the primary ways young black folks learned about race politics'. So, too, does it appear that the increasing reach of internet communications and, particularly, social media is expanding the scope of youth knowledge and engagement in civic discourse (Brimacombe et al. 2018). Sionlelei Mario is a civil society activist from Fiji who has worked on civics education programs in Fiji. She explained to me how social media is opening up channels of dialogue across the citizen spectrum of Fiji, saying:

Social media has a lot of groups that are discussing stuff. Policy people are having discussions, youth are having discussions and then there are others who have gone past their time and they're still talking.

Facebook provides a platform that is seemingly increasing opportunities for civic discussion for Pacific peoples, old and young alike. 'Yumi Toktok Stret' is a Facebook page focused on Vanuatu civil society, with over 100,000 followers. A similar page existed in Solomon Islands between 2011 and 2018 called 'Forum Solomon Islands International' (FSII), which, at its peak, had over 23,000 followers. One of the facilitators of FSII, Benjamin Afuga, discussed with me the potential power of social media to communicate public sentiment to leaders and to agitate for social change, stating: 
We believe that people's views on Facebook can be a useful tool to bring issues across to our leaders and others who might have an answer to these things.

Disenfranchisement with the current state of politics further appears to be influencing increased youth civic engagement. Multiple interviewees spoke of the political processes that discriminate against marginalised communities and that push the concerns of youth to the side as motivating their own engagement. Jope Tarai expressed his frustration that:

The current power structures that we have in Fiji are pro-elite, anti-youth, anti-poor. Not them personally, but the way the parliament is structured.

Such an assertion is echoed by Harry Olikwailafa, who stated:

We have a lot of good policies but the political will behind those policies [is lacking]. Sometimes you can see the political interference at administrative level.

It is important to note that these issues are not contained to the Pacific. In a study of seven youth communities across Central, North and South America, sociologists Jessica Taft and Hava Gordon $(2011,2013)$ identified frustration with political systems as a driver of youth civic engagement. Taft and Gordon (2013, p. 98) even suggested that youth engagement in activist civil society demonstrates that these youth are deeply committed to meaningful democracy and participation'. Rather than embodying identities that are focused on individual ambition and achievement — shaped by forces of modernisation, including international development discourses of capabilities and empowerment (Cornwall \& Brock 2005; Kleine 2010; Makuwira 2018)—several Pacific youth are finding ways to engage in their societies to benefit what they perceive as the common good. The case studies presented in this chapter indicate that a desire to work for 'common good' interests resonates with civically minded Pacific youth.

This commitment to democratic engagement with civil society was a recurrent theme in the interviews that I held with young civic activists. Young people engaged in critical civil society in Solomon Islands considered it their duty to promote the interests of youth and to hold the government to account for its transgressions and corruption. John Firibo, a youth group leader in Solomon Islands stated: 
In the schools, especially when it comes to history, we talk a lot about the politicians and there is a growing tension between us and the politicians. Many of us are trying to stamp out corruption in a way that they will see us, they will hear us and maybe make change.

In Fiji, this sense of frustration among youth interviewees regarding their marginalisation from civic and political practices was even more palpable due, at least partially, to the fact that 2014 had seen those aged under 30 years voting for the first time in the eight years since the beginning of military rule. The 'coup babies', as they are known (Vakaoti 2014, p. 5), appeared to revel in the opportunity to finally exercise their democratic rights and to openly discuss their concerns with friends, family and the public. Sionlelei Mario of Fiji explained this enthusiasm:

I'm in my 20s and most of my friends are around that age group and, for most of us, it was our first time to vote. We thought we had some obligation since we were sensitised in that area of national development and youth roles [as civically engaged young people]. We needed to get involved with other young people who are just coming out of their late teens to discuss what we think your role is, what your level of interest is in the general elections and what does it mean as a young person to actually tick that box [on the ballot paper] at the end of the day.

This should not be taken as a generalisation of youth approaches to engage with governance structures. Indeed, the youth activists who I interviewed were notable precisely for the depth of critical engagement that they have with political agents and structures in comparison with their peers.

\section{Conclusion}

The case studies of Be the Change, 350 Pacific and the emerging youth activists of Fiji and Solomon Islands demonstrate not only that there are youth willing to engage in meaningful ways in the shaping of their societies, but also that they have the skills to do so. Providing opportunities for young people to be positively engaged in civil society opens the prospect for a far greater number of youth to affect the futures of their communities, countries and the Pacific region for positive developmental change. The case studies also document the ability of young people to create their own opportunities for civic engagement when none are provided. 
Appropriate modes of participation are too often determined through an adult-centric lens. Parents and elders minimise youth participation daily and yet expect young people to be able to engage in systems that are designed for and by adults - and only when the adults believe that engagement is necessary or beneficial. As Vakaoti (2014, p. 24) found in a study of youth civic engagement for Fiji's Citizen's Constitutional Forum, 'Nuclear families, schools and social media were identified as popular spaces where young people could express their opinion. Adult spaces like community and church meetings were the least comfortable spaces for young people'. The specific mention of online platforms as spaces for youth civic engagement supports my own observations and data drawn from informants. Thus, it appears appropriate that when desiring youth engagement and participation, thought is put into where, when and how young people will feel most comfortable and valued to share their knowledge and opinions.

Again, it must be noted that the youth activists discussed in this chapter are not representative of the everyday civic engagement practices of all Pacific youth. For most, deference and passivity are the norm, guided by notions of 'tradition' and the social expectation that they 'be seen but not heard'. As Vakaoti (2012, p. 11) wrote, 'This is the enduring challenge for young people's participation in Fiji: how to successfully negotiate the past and the present?' Against the sociocentric backdrop of traditional communities and the increasing global influence of materialism and individualism, their challenge is to negotiate change in the roles that they play in society and in the roles that their societies play in the global environment. Chris McMurray (2006, p. 5) summarised this difficulty:

Especially difficult for young people is that many of the values and practices of a modern society are in direct conflict with those of their traditional societies. Traditional societies tend to resist change and questioning of their identity, whereas modern society promotes freedom and democracy, new ideas, discussion and debate.

Overcoming hierarchical hindrances to youth participation requires more than soliciting information from young people regarding issues that are important to adults or organisations that they represent. For the long-term, meaningful participation of young people, youth need to be empowered to appreciate that their contributions can be valuable, and people in decision-making positions need to truly recognise their value. Ideas of 
who is 'expert' enough to have their opinions considered have provided insight into the power with which knowledge is observed to be held, both by governing powers (Brownhill 2009, p. 360) and from Western centres of thought, such as academia and bilateral aid agencies (Mahiri 1998). Reversing this trend is not simple. It requires the commitment of experts, policymakers and young people alike to be open to the possibilities of youth engagement leading to positive outcomes. Examples such as those from Be the Change, 350 Pacific and the growing networks of youth activists and advocates demonstrate that such outcomes are possible.

\section{Acknowledgements}

My utmost gratitude to the communities, youth activists and advocates whom I met and spoke with in Fiji and Solomon Islands. My research is simply a reflection of their knowledge and lived experiences. Thank you also to La Trobe University for the financial assistance that supported the period of fieldwork from which the data represented in this chapter were collected.

\section{References}

350 Pacific n.d., We Don't Normally Do This Here in Kiribati ..., 350 Pacific, viewed 6 December 2016, 350pacific.org/we-dont-normally-do-this-here-inkiribati/

350.org n.d., Home Page, 350.org, viewed 6 December 2016, 350.org/

Aspire Network 2012, Aspire Network, Facebook, viewed 17 October 2018, www.facebook.com/pg/aspirenetworkfj

Bessant, J 2004, 'Mixed messages: Youth participation and democratic practice', Australian Journal of Political Science, vol. 39, no. 2, pp. 387-404, doi.org/ 10.1080/1036114042000238573

Brimacombe, T 2017, 'Pacific policy pathways: Young women online and offline', in M Macintyre \& C Spark (eds), Transformations of gender in Melanesia, ANU Press, Canberra, doi.org/10.1002/app5.253

Brimacombe, T, Kant, R, Finau, G, Tarai, J \& Titifanue, J 2018, 'A new frontier in digital activism: An exploration of digital feminism in Fiji', Asia and the Pacific Policy Studies, vol. 5, pp. 508-521. 
Brownhill, S 2009, 'The dynamics of participation: Modes of governance and increasing participation in planning', Urban Policy and Research, vol. 27, no. 4, pp. 357-375.

Carter, G 2015, 'Establishing a Pacific voice in the climate change negotiations', in G Fry \& S Tarte (eds), The New Pacific Diplomacy, ANU Press, Canberra, doi.org/10.22459/NPD.12.2015.17

Chattier, P 2016, Fijis Roshika Deo-Outlier, Positive Deviant or Simply Feisty Feminist?, Developmental Leadership Program, viewed 30 November 2016, www.dlprog.org/opinions/fiji-s-roshika-deo-outlier-positive-deviant-orsimply-feisty-feminist.php

Connell, T, Carr, M \& Kirkwood, I 2016, 'Newcastle Harbour coal blockade: Live updates', Newcastle Herald, 8 May 2016, viewed 23 June 2017, www. theherald.com.au/story/3894106/newcastle-harbour-coal-blockade/

Cornwall, A \& Brock, K 2005, 'What do buzzwords do for development policy? A critical look at "participation", "empowerment" and "poverty reduction"”, Third World Quarterly, vol. 26, no. 7, pp. 1043-1060.

Cox, J 2017, 'Kindy and grassroots gender transformations in Solomon Islands', in M Macintyre \& C Spark (eds), Transformations of gender in Melanesia, ANU Press, Canberra, doi.org/10.22459/TGM.02.2017.03

de Tocqueville, A 1947, Democracy in America: A new translation by Arthur Goldhammer, Library of America, New York.

Fraenkel, J 2008, 'The impact of RAMSI on the 2006 elections', in S Dinnen \& S Firth (eds), Politics and state building in Solomon Islands, ANU E Press, Canberra, doi.org/10.22459/PSBS.05.2008.06

Harris, A 2006, 'Introduction: Critical perspectives on child and youth participation in Australia and New Zealand/Aotearoa', Children, Youth and Environments, vol. 16, no. 2, pp. 220-230.

hooks, b 1990, Yearning: Race, gender, and cultural politics, South End Press, Boston.

Jayaweera, S \& Morioka, K 2008, Giving South Pacific youth a voice: Youth development through participation, International Bank for Reconstruction and Development/World Bank, Suva.

Jolly, M 1994, 'Hierarchy and encompassment: Rank, gender and place in Vanuatu and Fiji', History and Anthropology, vol. 7, nos 1-4, pp. 133-167, doi.org/10.1080/02757206.1994.9960843 
Kaiku, P 2017, 'Re-thinking the youth bulge theory in Melanesia', Contemporary PNG Studies: DWU Research Journal, vol. 26, pp. 1-14.

Klarman, MJ 1994, 'Brown, racial change, and the Civil Rights Movement', Virginia Law Review, vol. 80, no. 1, pp. 7-150.

Kleine, D 2010, 'ICT4What? - using the choice framework to operationalise the capability approach to development', Journal of International Development, vol. 22 , no. 5, pp. 674-692.

Mahiri, I 1998, Comparing transect walks with experts and local people, vol. 31, International Institute for Environment and Development, London, pp. 4-8.

Makuwira, J 2018, 'Power and development in practice: NGOs and the development agenda setting', Development in Practice, vol. 28, no. 3, pp. 422431, doi.org/10.1080/09614524.2018.1433816

McLeod, A 2007, Literature review of leadership models in the Pacific, State, Society and Governance in Melanesia Program, The Australian National University, Canberra.

McLeod, A 2015, Women's leadership in the Pacific, Developmental Leadership Program, University of Birmingham, Birmingham.

McMurray, C 2006, 'Young people's participation in the Pacific-facilitating factors and lessons learned', paper presented at the Children's Rights and Culture in the Pacific Seminar, UNICEF, Suva.

Morton, H 1996, Becoming Tongan: An ethnography of childhood, University of Hawai'i Press, Honolulu.

Nilan, P, Cavu, P, Tagicakiverata, I \& Hazelman, E 2006, 'White collar work: Career ambitions of final year school students', International Education Journal, vol. 7, no. 7, pp. 895-905.

Noble, C, Pereira, N \& Saune, N 2011, Urban youth in the Pacific: Increasing resilience and reducing risk for involvement in crime and violence, United Nations Development Program Pacific Centre, Suva.

Owen, D 1996, 'Dilemmas and opportunities for the young active citizen', Youth Studies Australia, vol. 15, no. 1, pp. 20-23.

Packard, A 2014, Coal Ships Stopped. The Warriors Have Risen!, 350 Pacific, viewed 6 December 2016, world.350.org/pacificwarriors/2014/10/20/coalships-stopped-the-warriors-have-risen/

Palet, LS 2014, Roshika Deo: Fijis Feminist Voice, OZY, viewed 30 November 2016, www.ozy.com/rising-stars/roshika-deo-fijis-feminist-voice/34034 
PIFS n.d., Youth, Pacific Islands Forum Secretariat (page discontinued), viewed 5 February 2018, www.forumsec.org/pages.cfm/newsroom/documentspublications/youth.html

Prasad, S 2017, 'Governance paradoxes and pathways in Pacific Island countries', Pacific Dynamics, vol. 1, no. 2, pp. 325-339.

Sahlins, M 1963, 'Poor man, rich man, big-man, chief: Political types in Melanesia and Polynesia', Comparative Studies in Society and History, vol. 5, no. 3, pp. 285-303.

Slatter, C 2006, 'Treading water in rapids? Non-governmental organisations and resistance to neo-liberalism in Pacific Island states', in S Firth (ed.), Globalisation and governance in the Pacific Islands, ANU E Press, Canberra, doi.org/10.22459/GGPI.12.2006.02

SPC 2009, The Suva Declaration from the 2nd Pacific youth festival: Actioning the youth agenda, Secretariat of the Pacific Community, Suva.

SPC 2015, The Pacific youth development framework 2014-2023, Secretariat of the Pacific Community Suva, Fiji.

Sukarieh, M \& Tannock, S 2017, 'The global securitisation of youth', Third World Quarterly, vol. 39, no. 5, pp. 854-870.

Taft, JK \& Gordon, HR 2011, 'Rethinking youth political socialization: Teenage activists talk back', Youth \& Society, vol. 43, no. 4, pp. 1499-1527, doi.org/ 10.1177/0044118X10386087

Taft, JK \& Gordon, HR 2013, 'Youth activists, youth councils and constrained democracy', Education, Citizenship and Social Literature, vol. 8, no. 1, pp. 87100, doi.org/10.1177/1746197913475765

Titifanue, J, Kant, R, Finau, G \& Tarai, J 2017, 'Climate change advocacy in the Pacific: The role of information and communication technologies', Pacific Journalism Review, vol. 23, no. 1, pp. 133-149, doi.org/10.24135/pjr. v23i1.105

Urdal, H 2006, 'A clash of generations? Youth bulges and political violence', International Studies Quarterly, vol. 50, pp. 607-629, doi.org/10.1111/ j.1468-2478.2006.00416.x

Vakaoti, P 2012, 'Mapping the landscape of young people's participation in Fiji', SSGM Discussion Paper 6, State, Society and Governance in Melanesia Department, The Australian National University, Canberra. 
PACIFIC YOUTH

Vakaoti, P 2014, Young people and democratic participation in Fiji, Citizens' Constitutional Forum, Suva.

Winter, JP \& Eyal, CH 1981, 'Agenda setting for the civil rights issue', Public Opinion Quarterly, vol. 45, pp. 376-383.

Wood, T 2015, 'The 2014 parliamentary elections in Solomon Islands', Electoral Studies, vol. 39, pp. 153-158, doi.org/10.1016/j.electstud.2015.03.006 
This text is taken from Pacific Youth: Local and Global Futures, edited by Helen Lee, published 2019 by ANU Press, The Australian National University, Canberra, Australia.

doi.org/10.22459/PY.2019.06 